\title{
By Any Other Name? The Impacts of Differing Assumptions, Expectations, and Misconceptions in Bringing About Resistance to Student-Staff Partnership
}

\author{
*Ruth L. Healey, Alex Lerczak, Katharine Welsh, and Derek France \\ Department of Geography and International Development, University of Chester, UK
}

\section{Contact: r.healey@chester.ac.uk}

\section{ABSTRACT}

Most of the existing literature on student-staff partnership explores the experiences of people who are keen to be involved and who have already bought into the ethos of Students as Partners. We explore the challenges of conducting student-staff partnership in the context of resistance. Specifically, we focus on the interpretations of partnership by students and staff who were attempting to work in partnership for the first time in a medium-sized geography department in the UK. The views of participants were captured during a six-month project in which four undergraduate students were employed to work with eight academics to redesign the second-year undergraduate curriculum of one programme. Notwithstanding an introductory briefing and ongoing support, some participants showed indications of resistance. Our findings suggest that different perspectives on partnership influenced participants' experiences. We argue that assumptions, expectations, and misconceptions around the terminology used to describe Students-as-Partners practice may hinder the process itself, as some people may not buy in to the practice. However, despite the challenges of this project, the experience of being involved in the re-design of the modules has led to reduced resistance and emerging partnership practices throughout the department.

\section{KEYWORDS}

students as partners, terminology, language, partnership, curriculum redesign, geography

Partnership offers opportunities to adopt alternative approaches to working with students, new modes of learning, and the potential for transformation of both the partners and institutions involved (Cook-Sather, Bovill, \& Felten, 2014; Taylor, 2015). However, inevitably in a field that challenges the traditional hierarchies and boundaries of higher education there is sometimes resistance to disruption of the traditional roles and responsibilities of staff and students (King \& Felten, 2012; Cook-Sather \& Luz, 2015; Matthews et al., 2018). To date, the majority of literature on partnership explores the 
experiences of people who are supportive of the ethos and values of partnership. Yet, resistance is likely to be stronger when working with people who are not already convinced by the notion of partnership.

This research explores the challenges of introducing partnership practice to staff and students new to the experience who engaged to achieve a particular outcome (the design of new courses) rather than because they wanted to develop new ways of working together. We analyse these participants' interpretations of partnership and how these interpretations influenced the experience of working together. We argue that assumptions, expectations, and misconceptions around the terminology used to describe Students-as-Partners practice may hinder the process itself. Despite being introduced to the existing literature and models of partnership, individuals may still not buy in to the practice.

Limited buy in has implications for the practice of partnership. In contexts in which participants are not already convinced of the value of partnership, initial partnership practice may have to take different forms than in some established partnership models such as that of pedagogic consultants (Ntem \& Cook-Sather 2018). Expectations about the process of developing partnerships may need to be reduced as some contexts are unable to reproduce the more intensive and immersive relationships achieved in some other academic contexts. Building an alternative model involves a balancing act between the time required to develop a partnership relationship and the willingness of people to commit to the experience. The members of new partnerships need to prioritise reflection on participants' preconceptions of partnership in the time available, so as to support members' understanding of the values and principles underlying the practice. We also recognise that change takes significant time and note that, despite the challenges involved in this project, the experience of being involved in these partnerships has enabled the participants to reflect on partnership, leading to reduced resistance to the practice and emerging partnership activities throughout the department.

\section{RESISTANCE TO PARTNERSHIP: ASSUMPTIONS, EXPECTATIONS, AND MISCONCEPTIONS}

The benefits of educational change are often in the eye of the beholder (March, 1991). Whilst the initiator of change sees it as logical and well thought-through, others may see it as illogical and improperly conceived and therefore be more likely to resist such change either implicitly or explicitly (Smit, 2003). Fink and Stoll (1998) argue that "resistance is a natural and predictable response" (299), as people perceive that change will impact them negatively (Sheth \& Stellner, 1979), create loss, confusion, and conflict, and/or challenge their competence (Smit, 2003).

Partnership is a process of student engagement "distinguished by the importance placed on the distribution of power" (Healey, Flint, \& Harrington, 2014, p. 15). It deliberately challenges the status quo and therefore is perceived by some as a threat to their identity (Ntem \& Cook-Sather, 2018). Working to alter the balance of power raises awareness of implicit assumptions different partners have about each other and thus threatens traditional roles and responsibilities that are intrinsically linked to student and staff identities (Cook-Sather \& Luz, 2015; Mercer-Mapstone, Marquis, \& McConnell, 2018). Consequently, in order for partnerships to be effective it would appear there needs to be a willingness to navigate these assumptions and work through the resulting impacts (Marquis, Black, \& Healey, 2015; Cook-Sather, 2014). 


\section{Assumptions, expectations, and misconceptions}

Partnerships in higher education challenge and stretch students and staff and may take both parties outside their comfort zones. In partnerships both students and staff take on the role of learners and teachers (Healey et al., 2014). It is important to recognise that both parties bring different, but comparable, experiences to the table (Higher Education Academy [HEA], 2015). Time and institutional support is needed to convince colleagues, and sometimes students themselves, that students have important insights about improving teaching and learning (Doktor, 2016) and that they have the maturity to make important decisions that have the potential to affect a large number of students (National Union of Students [NUS], 2015). Yet, these traditional power structures often affect academics and students in different ways. For example, the perception of tutor expertise may enable academics to dismiss student comments on the basis of their limited knowledge; it may also cause students to defer to the views of the staff and lack confidence in vocalising their own views and concerns (Bovill, 2014).

The belief that students do not possess the required expertise and so can never be equal partners disenfranchises them (NUS, 2015). This simplification dismisses the nature of the expertise that students bring to the partnership and suggests that knowledge of higher education is exclusively the domain of trained academics. Although students may be neither disciplinary nor pedagogic experts, they have significant expertise in being students (CookSather et al., 2014). This is knowledge that academics, either through being atypical students themselves and/or by not having been a student for many years, may not possess. Furthermore, students bring forms of knowledge based on their identities and life experiences, which are particularly important and relevant if either has been underrepresented (de Bie, Marquis, Cook-Sather, \& Luqueño, in press). Students can bring their experience of what they have found effective and ineffective. Academic staff can bring subject knowledge, teaching expertise, and guidance as to what is realistically possible within institutional structures. Finally, if partnership is considered to be a process (Healey et al., 2014), then whilst partners may not have equal responsibility for the outputs of their partnership, the different members of the partnership may have equal responsibility for ensuring a partnership approach to working together.

Yet even in accepting the potential of student-staff partnerships, some participants may be discouraged from the practice due to limited time and/or resources to engage fully. For students this may relate to needing to prioritize other competing commitments such as part-time work, their studies, and caring responsibilities. For academic staff this may connect to the perception that it is quicker and easier to do the work on their own (Curran \& Millard, 2016).

People may bring their own interpretations, assumptions, and sometimes misconceptions about partnership as the term evokes a variety of associations and reactions (Cook-Sather, Matthews, Ntem, \& Leathwick, 2018). Some of these may lead people to be resistant to the practice. Conversely, some of the literature may lead to pedagogic partnerships being interpreted as an ideal or an aspiration, or a positive process which achieves positive outcomes for partners (Mercer-Mapstone, Dvorakova, Groenendijk, \& Matthews, 2017). The lived experience of enacting the process of partnership may be accompanied by feelings of pressure to enact this idealised notion of the practice, missing the importance of recognising and confronting the messiness and conflicts that are the 
reality of practicing partnership (Mercer-Mapstone et al., 2017). Exploring these interpretations of partnership from the perspective of everyone involved offers an opportunity to confront different partner expectations from the beginning of the project and hence support the development of the partnership process. We now explore these challenges in the context of a case study in which partnership practice was introduced for the first time.

\section{CASE STUDY AND METHOD}

The Geography Department in a small university in the UK employed four undergraduate students to work with eight academics in 2016 to redesign the second-year undergraduate geography curriculum. The goal of the redesign was to produce four new year-long courses (on average 40 hours of class contact time between students and staff in each course). The teams aspired to work in partnership by involving students in course design as members of the development team. The project ran over a six-month period from January to June. The courses began delivery the following October.

This was the first project of its kind within the department, in an institution that did not have centralised support for working in partnership. Staff were invited to be involved in the project, but whilst it was by invitation, the supportive culture of the department may have meant that some staff felt they should get involved despite not necessarily being convinced by the notion of partnership between students and staff. The staff members included three junior lecturers, four senior lecturers, and a professor. The staff had no prior experience of working in partnership with students to design courses, although several of them worked with students in partnership in learning and teaching and in research and inquiry. Three of the staff members included in the partnerships were also involved in researching the partnership experience that is outlined within this paper. Whilst interested in and caring about teaching and learning within the context of high workloads and competing pressures on their time most of the staff involved felt unable to prioritise this initiative over their other commitments.

The opportunity for students to join the partnerships was advertised through the university's student job bank to all second- and third-year undergraduate geography students. Second- and third-year students were targeted so that the student partners had some experience of the existing second-year curriculum. Four undergraduate students with no prior experience of working in partnership were appointed: two physical geographers in the second year of their degree, and two human geographers in the third (and final) year of their degree. The appointed students were employed to work for 50 hours each over six months in one of two teams (one focusing on two human geography courses, the other on two physical geography courses). Table 1 provides the pseudonyms for the participants; gender-neutral pseudonyms were chosen to further protect the identity of the participants.

Conscious of the time both the staff and student participants were giving to be involved in the project in addition to already high workloads and a lack of existing support structures within the institution, we designed a light-touch approach to establishing and supporting the developing partnerships. Through a one-hour workshop all participants were introduced to definitions of student-staff partnership (Cook-Sather et al. 2014; Dunne \& Zandstra, 2011; Healey et al., 2014; Williamson, 2013), how partnership relates to other types of participation (Bovill \& Bulley, 2011), and to the HEA (2015) principles of 
partnership. They were also given the opportunity to review and discuss examples of partnership in other learning and teaching contexts. At the end of the meeting the respective partnership teams separated to discuss progressing the development of the modules for which they were responsible.

Table 1: Partnerships members and positions

\begin{tabular}{|l|l|}
\hline Pseudonym & Position \\
\hline Alex & Student \\
\hline Brook & Student \\
\hline Chris & Student \\
\hline Drew & Student \\
\hline Adrian & Academic \\
\hline Bobbie & Academic \\
\hline Charlie & Academic \\
\hline Dana & Academic \\
\hline Elliott & Academic* \\
\hline Frankie & Academic* \\
\hline Gray & Academic \\
\hline Hayden & Academic* \\
\hline
\end{tabular}

*Participants marked with an asterisk were also members of the research team conducting this study.

Over the course of the project the students participated in the design of the curriculum by discussing the specific content and order of that content, producing teaching resources, designing learning exercises, and piloting fieldwork ideas. A research assistant (not involved in either of the partnership teams) collected data on participant experiences in four stages. First, before the design of the courses commenced, the student and academic participants took part in separate focus groups exploring their expectations, aspirations, and plans for the courses and partnerships. Second, during the working phase of the project, each student kept a reflective diary of their experiences. Third, towards the end of the project, two focus groups with academics were conducted, one with the research team involved in the project, and one with the academics who had not been involved in the research of the partnerships. Fourth, individual interviews were conducted with each of the student partners. These end-of-project meetings explored participant experiences throughout the project by discussing how the partnerships operated, how this related to participants' interpretation of partnership, and how this related to the HEA principles and values for student-staff partnership (HEA, 2015). The data from each of these methods were coded inductively and key themes identified (Payne, 2007). An interpretive perspective was adopted in which social realities are understood as constructed and individual subjective experiences valued (Merriam, 2009).

During the project the research assistant acted as a mentor to the student participants. When the student partners shared their diary entries, the research assistant discussed their experiences with them and where appropriate offered support and 
guidance. Staff support was approached more informally-primarily through responding to direct queries and corridor discussions.

\section{ASSUMPTIONS, EXPECTATIONS, AND MISCONCEPTIONS UNDERLYING THE STUDENT-STAFF PARTNERSHIP PROJECT}

All of the staff and student participants in this project suggested to us that they recognised the value of working together to develop the new courses. Yet, it appeared that some participants found the label of partnership as a description of this working arrangement to be troublesome due to their apparent assumptions or possible misconceptions underlying the term (Cook-Sather, 2014; Marquis et al., 2015). We noticed that all of the students seemed to take it for granted that partnership was achievable at the start of the project. In contrast, some of the staff responses suggested they were more resistant to the term. For example, Dana commented:

I absolutely see the value of meaningful student input and engagement around the design of new modules (etc.) but I do find framing this as "partnership" immensely problematic. ... Collaboration, maybe, but partnership, no.

Partnership is "multi-faceted and has a number of different meanings and purposes dependent on context" (Healey et al., 2014, p. 23). Dana's interpretation of the student input may support an understanding of partnership as a process. Yet, the apparent resistance to the term partnership here may relate to Dana associating partnership with the output. In this way, the different participants in this research brought their own assumptions and understandings to partnership practice and what they perceived as possible within the broader higher education context. We noticed that these interpretations influenced their level of satisfaction within the partnerships. Broadly speaking, the interpretations that led to dissatisfaction with partnership fell into four different categories: (a) misconceptions about equality within partnership, (b) expectations about the nature of partner contributions, (c) expectations about the process of partnership, and (d) assumptions about authentic engagement in the project. These findings are presented and discussed in relation to the literature.

\section{Equality in partnership}

Equality - the state of being equal-within partnership was brought up in the first focus groups by both students and staff before the project had begun. There are important differences between the adjectives equal, equitable, equivalent, and same. The Oxford Living Dictionary (2018) defines equal as "having the same status, rights, or opportunities;" equitable as "fair and impartial;" equivalent as "equal in value, amount, function, meaning;" and same as "identical; not different." Partnership practice is often critiqued on the basis that it is not possible for all partners to be the same, or do identical work in a partnership (NUS, 2015). However, the term equal is sometimes used instead of the same. Sameness in partnership is a misconception. We found that both students and staff used the term equality to discuss the division of work and responsibility for the course production, though 
they appeared to use the term in different ways. In relation to the experience of partnership two of the students referred to being equal in different ways:

you're on equal footing and sort of everything's shared, so it's like shared responsibility, shared like respect, but sharing of ideas and everything. So, it's like an equal contribution for everything really ... I sort of link it to like business partners, . . . one person may look at one aspect, ... they sort of divvy up control, but they sort of both have equal weight. (Brook)

working together with other people and just making sure you're all kind of on equal grounding, [and] have an equal say in what can happen. (Chris)

The reference to partnership being like business partners reflects one of the classic definitions of partnership where "partners contribute the same amounts of capital and divide the work equally" (Ingels, 2009, p. 531). Brook's comment may therefore appear to verge upon notions of sameness within pedagogic partnerships. Overall, however, these interpretations of partnership suggest a sharing of responsibility, respect, and ideas as defined by the notion of equal contributions (Cook-Sather \& Felten, 2017).

When the students were asked to describe what they anticipated to be the distribution of work between themselves and the staff they indicated that the distribution ranged from staff and students sharing equally in the work, to staff accounting for $60 \%$ and students $40 \%$. Drew commented that the balance of work within the partnership was:

not fifty-fifty because ... I don't necessarily have to be like... in the deep end of the project. . . I I can add my partnership to it, but not like necessarily, be in charge of like a whole section of it.

Drew appears to associate the "deep end" of a partnership project with a measurement of quantity: "a whole section." This dismisses the potential for high-quality contributions that are equivalent to "a whole section"; for example, an original idea which significantly enhances the whole course. This is an example of the conflation of equal with the same. It also suggests equality in partnership is related to the output rather than the process.

The staff members also brought up the notion of equality. Adrian appeared to believe that partnership meant sameness of those involved, and therefore that partnership was not possible in this context. They explained: "I don't see how that's going to be achieved, sort of, because you've got different knowledge bases of what they can bring and what you can offer." This statement suggests that partnership requires the knowledge that people bring to the discussion be the same (NUS, 2015), and that if they do not bring this same knowledge, then partnership is not possible. Some staff participants also appeared to consider equality specifically in relation to responsibility for the output from the partnerships, for example, in relation to the quality of the courses:

I think part of the issue is probably, culpability. Although we're going to be working together to put the module together, ultimately, it's going to be the staff that deliver it and are held responsible for its success. Whereas the students will be part of the 
project and then, essentially walk away, and I think that makes it very difficult to, to feel that the kind of burden is equal to some extent. (Charlie)

Staff experience and expertise underlies quality assurance processes, hence overarching responsibility for delivery and assessment rests with them. As Woolmer et al. (2016) found, students may lack the knowledge of these broader requirements. However, as demonstrated above, this was recognised by the students; indeed, they did not aspire to have that level of responsibility for the output of the project. Rather, equality was possible in the process of partnership, as one academic explained:

I think it's about, equal but differentiated responsibility, because ... the differentiated element I think is really, key, for me, ensuring that students have ownership over appropriate parts of the teaching and learning process, but, we as leaders and facilitators of that process are clear about what the boundaries are between our responsibilities and theirs. (Dana)

While seeming to identify differentiated levels of responsibility in this context, Dana assumes that it is the staff who have overarching responsibility for both the process and the outcomes. We read this quotation as suggesting that Dana thinks that staff will therefore be the ones setting the boundaries of student involvement. This perception establishes the staff member as the gatekeeper to what involvement is appropriate for students. Elsewhere it has been argued that partnership is a two-way process in which the staff member(s) may learn from the student(s) (HEA, 2015). Beginning the partnership with discussion and negotiation between the partners as to how they might operate as a team and identifying where the students and staff feel their different expertise would contribute most to the design of the course would offer a more open approach.

In contrast, Hayden commented that partnership was having "different viewpoints on the same topic and the same ways of doing things" but the aim is to find some common ground and reach a consensus. Furthermore, Frankie argued that: "If you're saying, well the buck stops with me, so it can't be a partnership, the buck stops with [the Head of Department]. That doesn't mean they do everything." This perspective appears to acknowledge that different people have different responsibilities and status within partnership, or that the work is shared equitably (Cook-Sather et al., 2014). Frankie's analogy considers how they work with colleagues, recognising that, although responsibility for the successful running of a department is that of the Head of Department, staff still have ownership of the work they do, or differentiated responsibilities for aspects of running the department. Whilst in contrast to Dana's perspective, this assumption also brings challenges to the success of a partnership, as it does not adequately recognise the potential needs or expectations of the different partners in the process of partnership.

\section{The nature of partner contributions}

Staff and students seemed to have particular expectations about the contributions that students might make-the activities in which they might be involved and the knowledge and ideas they might bring to the table. For instance, it appeared that some staff entered into the partnership expecting that students would share ideas that were not 
feasible: "I can imagine that they'll make several suggestions, and straight away, it will be sort of a harsh we'll have to say, well no sorry, can't" (Adrian). This follows the NUS (2015) findings that staff perceived students to lack the experience or maturity to make important decisions. Unfortunately, expecting to say "no" establishes a barrier in a discussion before it has begun and suggests some staff members did not anticipate student contributions to be appropriate (Cook-Sather et al., 2014). An alternative approach would be for staff to share their knowledge of structural limitations (e.g. timetable structures and deadlines) with students and for them to reflect together on each idea to see if it could be facilitated and what the implications of that would be. At the end of the project, Adrian did not consider the practice to have been a partnership because "everything that I wanted to go in that module has gone into it." This implies that Adrian expected working in partnership to alter the content of the module. However, this does not mean that the way in which the decisions on content were made, and the detail of the topics covered, were not affected by the input of the student partners. Furthermore, we recognised that the students themselves placed limits on what they could offer to design of the curriculum. For example, Chris stated: "I can't produce a lecture slide to deliver to, because I don't have that knowledge, so I physically can't add that element into it." The perception that Chris cannot contribute to the content of a lecture established parameters to what they could do before the project had started. These reflections suggested to us that the students may not have recognised, or at least did not name, the unique insights that they do bring (Cook-Sather et al., 2014). What both these examples focus on is what the students could not contribute to the process rather than the possibilities to go beyond the normative category of "student." For some, the nature of the student involvement in the project appears to have been a foregone conclusion from the beginning.

Some of the comments that students made seemed to suggest that they also had expectations about what the staff might contribute. For example, Brook commented:

For quite a few of them, it's been a long time since they were a student, in the nicest way possible.... And so, do they still... like, do they realise that since they were a student, things may have changed, or have they forgotten that because they've got their lecturer hat on? Do they still sort of relate to the students and know what they want, or do they make it their business to find out?

As a 20-year-old second-year undergraduate student, Brook perceived staff to have forgotten what being a student was like. However, two of the staff members were still formally classed as also being students, as they were new staff who were completing their postgraduate certificate in teaching and learning in higher education. Whilst we recognise that being formally classed as a student may be different from having recent experience as an undergraduate, many students on the postgraduate certificate course have noted how quickly they returned to performing as they did as undergraduate students. The assumption, therefore, that staff had no recent experience of being students suggests a lack of recognition of the nuanced experiences of the individuals involved. 


\section{The process of partnership}

In the first focus group both Drew and Chris expressed their perception that the partnerships should be discussion-based: "all sharing ideas, and then working together, to help create one thing" (Drew). This expectation, and the earlier assumptions of Frankie and Dana, appeared to underlie their different interpretations of their experiences of partnership. Earlier it was noted that Frankie planned to approach working with the students in the same way as they would with other staff colleagues - this was based on meetings to discuss and plan what was to be developed with follow-up tasks to produce resources. Frankie stated:

I feel that, the production of resources and the discussions that we've had, have been two-way, and, have, led to different, outputs and different products on the basis of them producing something themselves, and therefore, I think that; that to me feels more like a partnership.

Here Frankie had moved out of the traditional academic role of creating the resources, to critiquing and discussing the materials generated by the students (Woolmer et al., 2016). However, we noticed that the student partners "felt more like... being given a task, and having to do it, and come back and report" (Chris). For Drew this felt "like then Frankie has marked it, and then we're just kind of amending it," causing Drew to go on to question what Frankie was contributing to the production of the course. This parallels Abbot's (2018) findings in which the student partners felt like assistants rather than partners when the staff partner already knew what they wanted and appeared to assign work to the students. In contrast, the students appeared to consider the process to be more of a partnership when they worked with Dana:

We're the same, because we've just been discussing. . . . And we've literally, all of us sat there and unpicked it. They've treated it like a blank slate as well. So, I feel like that input was basically the same.... Which I suppose is more partnershippy. (Drew)

Chris comments: "it felt more like a partnership [with Dana] because we were running the ideas together in one session." This comment appears to suggest that they felt that partnership happens when the partners were all together working on and discussing the course. This assumption may have prevented the students from viewing co-produced resources as also being partnership. If so, this goes against the argument that students should be enabled to identify both the areas for enhancement and how that enhancement is achieved (Williamson, 2013). Furthermore, Dana questioned whether their "looser" approach to working with the students had been "a bit of a barrier," as the students had not produced any resources for the course they were working on together. Indeed, one of the students expressed that to one staff partner that "they preferred being in the advisory role, rather than doing the work" (Elliot). Some of the students enjoyed the discussion, but were resistant to engaging in co-production. Whilst partnership is primarily a process, not an outcome (Healey et al., 2014), the students and staff had the opportunity to work together to co-produce materials for the course. 


\section{Authentic engagement in the project}

The staff and student participants in this project were all invited. However, we learnt at the end of the project that, in the highly collegial department, some of the staff members had felt pressure to participate as they had wanted to support their colleagues and their work. Indeed, for some staff their dominant perception of their involvement was as "a favour": "I'm doing this for a favour to [the research team], more than anything else, so... it's not been my priority" (Dana). In contrast, the instigators of the project had assumed that this would be an opportunity that their colleagues would welcome:

Frankie: That's really unfortunate because I thought we were offering them [staff] a resource, that they wouldn't have normally have had, and so I saw it as, this is an awesome opportunity.

Hayden: But they saw it as, and I quote, "more work."

Echoing Curran and Millard's (2016) findings, some of the tutors appeared to find working in partnership a drain on their limited time noting that it is quicker and easier to do the work on their own. The assumption of the research team, that the staff would enthusiastically appreciate this opportunity and see the value in working in partnership, supports March's (1991) view that change in education is in the eye of the beholder, and resistance is to be expected (Fink \& Stoll, 1998).

Overall, staff resistance might have been reduced if the funding for the partnership project had been available without being tied to a research project: "I wonder if like the presence of a research team, or the research project [affected the experience]" (Elliott). In a teaching-intensive institution where time for research is at a premium, giving up time for what is perceived as someone else's research appeared to create some resentment: "I' $m$ afraid I'd be unlikely to change how I work for the sake of someone else's project" (Dana). The expectations of both the research team and the staff appear to have limited the success of the project. First, the assumption that staff would want to be involved meant that not enough was done to ensure staff knew that they did not have to be a part of the project in the first place. Second, the perception that this was "someone else's project" suggests that ownership by some staff members was restricted and that therefore they were not authentically engaged.

These perceptions reveal the complexities when using the term partnership and the assumptions and misconceptions that underlie it. These types of views and concerns can inhibit engagement and investment in partnership projects like this one, hindering their chances of success from the start. As discussed earlier in relation to the broader partnership literature, the difference in knowledge, skills, and ability to contribute is not necessarily an issue when working together as a partnership. While partnership does not require a false equivalency, it does mean that all partners have an equivalent opportunity to contribute to the process, but not that all partners have to contribute the same amount or in the same way (Cook-Sather et al., 2014; HEA, 2015; Felten, 2013). In this study, many of the participants, both staff and students, appeared not to share this view, and we noticed that their assumptions and misconceptions of what partnership involved or what partnership could be seemed to be oversimplified. It is therefore desirable to make these meanings 
explicit at the beginning of a partnership and provide time during the partnership to unpack them.

\section{CONCLUSION}

In this paper we have contributed an analysis of how different perspectives on partnership can influence participant experiences. Working in partnership raises awareness of the implicit assumptions different partners have about each other (Healey et al., 2014). However, as this research has demonstrated, raising awareness of such ingrained assumptions or expectations does not in itself overcome the barriers that they create. This project experienced resistance as it attempted to bring in partners who were new to partnership in a context without existing support structures. This meant that the types of support in place at centres of partnership practice, such as the Students as Partners Programme at McMaster University and the Students as Learners and Teachers Program at Bryn Mawr College (Ntem \& Cook-Sather, 2018), were not available. Notwithstanding an introductory briefing and ongoing support, some participants expressed reservations that suggested they were not convinced by the ethos of partnership, or at least the language associated with it.

Whilst most of the staff participants identified significant benefits to working with students in a collaborative manner, this did not necessarily mean that they bought in to partnership practice. Despite recognising value in student-staff partnerships, some appeared to be dismissive of the Students as Partners agenda due to their preconceptions or misconceptions of what a partnership entails. They needed more support to take ownership of nuanced views about partnership, but they were reluctant to commit to the extra time that this would have involved. In time-limited contexts, people are often more output rather than process orientated-here the staff wanted to develop a new curriculum, and the students wanted to work with them to do this. They were less concerned about the process of how they were going to work together. Unless the partners are able to reflect on their different interpretations of partnership, then their understanding of partnership will be limited. This requires a trade-off between the amount of time needed to develop effective partnership relationships and the pragmatism of being able to achieve the desired outputs in the context of limited time and resources.

The language we use to describe Students-as-Partners practice has a powerful influence on the perceptions of what the practice involves. To paraphrase Shakespeare (1599), "What's in a name? that which we call [Partnership] by any other name would [still be worthwhile]" (Act II, Scene II, Line 43-44). Whilst the name "partnership" does not determine the nature of the practice, it is imbued with assumptions and expectations (CookSather et al., 2018), which influence the way partnership plays out in particular contexts (Healey \& Healey, 2018). For example, it may be down to context as to whether or not teams decide to use the terminology of "partnership" initially, or if they decide to build capacity in the practice of working together using more familiar terms like "collaboration" or "co-design", perhaps bringing in the language of partnership later (Luo, Matthews, \& Chunduri, in press). This strategy may be particularly appropriate where teams are able to plan beyond a single project, so as to build confidence and understanding over several projects in a way that allows them to change the terminology as practice and experience are developed. When the term "partnership" is used, we need to ensure that time is included at 
the beginning of new partnerships to unpack the language and discuss the assumptions in different interpretations of the term. This provides the opportunity for participants to take ownership of the practice and manage their expectations as to what is possible in their specific context. This necessitates going beyond simply defining the words, and rather teasing out the assumptions and possible misconceptions each individual has, so as to move towards a shared understanding of partnership between the specific partners. This may be led by people who already perceive the benefits of the practice so as to guide and support the team as they learn from one another. Partners may then begin working together with a shared, albeit uncertain, understanding of partnership.

Whilst this paper has focused upon the challenges of undertaking the partnership project, there were also many positive outcomes. These include four new modules that have been popular with successive student cohorts, enhanced understanding and learning about partnership within the department, and the infiltration of partnership approaches into many other areas of the department (e.g. teaching sessions, prospective student visit days, and other enhancement activities across the department). Time to process this experience of partnership and reflect upon the participants' initial perceptions of the language has led to an embedding of at least some of the ethos of partnership across the department including among people who were not involved in the original project. Despite the challenges involved in this first partnership project, the experience of working together in this way has reduced resistance to the practice. We must not underestimate the time and support needed for people to adjust to and adapt to change. Key to this is recognising the emotional responses people experience as they work through new approaches, especially those that challenge their identity (Ntem \& Cook-Sather, 2018). As Felten (2017) has argued, further research is needed into the emotional experiences of working in partnership and how these might be supported.

Engaging in partnership can be messy and ambiguous. Yet, initial resistance to this ambiguity provides openings for discussion and critical analysis, and opportunities to learn by working through these tensions. Widening people's perspectives on Students-as-Partners practice by challenging and exploring their assumptions about partnership should help ensure that more future partnerships turn out to be "amazingly affirmative and stimulating experience for all parties” (Healey \& Healey, 2018, p. 6).

This research was successfully reviewed according to the Ethics Committee of the Learning and Teaching Institute at the University of Chester, UK.

\section{ACKNOWLEDGEMENTS}

This research was funded by Research Excellence Framework monies through the Research Knowledge Transfer Office, University of Chester. We would like to thank the four students for participating in this research and their insightful contributions to the development of the undergraduate programme. We would also like to thank the five staff members who took the time to not only experiment with working in partnership but also made time to participate in this research project. We gratefully acknowledge the significant support and advice from both the Editors and Reviewers of this paper. Their constructive and thoughtful insights have significantly enhanced this paper. 


\section{NOTES ON CONTRIBUTORS}

Ruth L. Healey is an Associate Professor in Pedagogy in Higher Education at the University of Chester, UK. In 2016, she also joined Healey HE Consultants. She is a Senior Fellow of the Higher Education Academy and in 2017 became a National Teaching Fellow.

Alex Lerczak is a Graduate Consultant in the Social and Market Research Team at AECOM. He has a First-Class BSc degree in Geography, as well as an MSc in Sustainability for Community and Business (Distinction). He worked as a Research Assistant at the University of Chester from 2016-2017.

Dr. Katharine Welsh is a Senior Lecturer in Physical Geography at the University of Chester and a Fellow of the Higher Education Academy. She is an advocate of technology-enhanced learning and is part of the Enhancing Fieldwork Learning team.

Derek France is a Professor in Pedagogy and Geosciences. He is Deputy Head of the Department of Geography and International Development at the University of Chester, UK. In 2008, he became a National Teaching Fellow.

\section{REFERENCES}

Abbot, S. (2018). What happens if disagreement in partnership is unevenly experienced? [blog post]. Retrieved from https://www.centerforengagedlearning.org/whathappens-if-disagreement-in-partnership-is-unevenly-experienced/

Bovill, C. (2014). An investigation of co-created curricula within higher education in the UK, Ireland and the USA. Innovations in Education and Teaching International, 51(1), 15-

25. https://doi.org/10.1080/14703297.2013.770264

Bovill, C., \& Bulley, C. J. (2011). A model of active student participation in curriculum design: Exploring desirability and possibility. In C. Rust (Ed.), Global theories and local practices: Institutional, disciplinary and cultural variations (pp. 176-188). Oxford: Oxford Brookes University, Oxford Centre for Staff and Learning Development.

Cook-Sather, A. (2014). Student-faculty partnership in explorations of pedagogical practice: A threshold concept in academic development. International Journal for Academic Development, 19(3), 186-198. https://doi.org/10.1080/1360144X.2013.805694

Cook-Sather, A., Bovill, C., \& Felten, P. (2014). Engaging students as partners in teaching \& learning: A guide for faculty. San Francisco, CA: Jossey-Bass.

Cook-Sather, A. \& Felten, P. (2017). Ethics of academic leadership: Guiding learning and teaching. In F. Su \& M. Wood (Eds.), Cosmopolitan perspectives on academic leadership in higher education (pp. 175-191). London: Bloomsbury Academic.

Cook-Sather, A., \& Luz, A. (2015). Greater engagement in and responsibility for learning: What happens when students cross the threshold of student-faculty partnership. Higher Education Research \& Development, 34(6), 1097-1109. https://doi.org/10.1080/07294360.2014.911263 
Cook-Sather, A., Matthews, K. E., Ntem, A., \& Leathwick, S. (2018). What we talk about when we talk about Students as Partners. International Journal for Students as Partners, 2(2), 1-9. https://doi.org/10.15173/ijsap.v2i2.3790

Curran, R., \& Millard, L. (2016). A partnership approach to developing student capacity to engage and staff capacity to be engaging: Opportunities for academic developers. International Journal for Academic Development, 21(1): 67-78. https://doi.org/10.1080/1360144X.2015.1120212

de Bie, A., Marquis, E., Cook-Sather, A., \& Luqueño, L. (2019, in press). Valuing knowledge(s) and cultivating confidence: Contributing to epistemic justice via student-faculty pedagogical partnerships. In J. Hoffman, P. Blessinger, \& M. Makhanya (Eds.), Strategies for fostering inclusive classrooms in higher education: International perspectives on equity and inclusion (Vol 16, pp. 35-48). Bingley, UK: Emerald Publishing Limited.

Doktor, S. (2016, January). 5 ideas to shift learning into a co-created teacher and student partnership [blog post]. Retrieved from http://www.pearsoned.com/educationblog/5-ideas-to-shift-learning-into-a-co-created-teacher-and-student-partnership/

Dunne, E., \& Zandstra, R. (2011). Students as change agents: New ways of engaging with learning and teaching in higher education. Bristol, UK: Escalate. https://dera.ioe.ac.uk//14767/7/8242 Redacted.pdf

Felten, P. (2013). Student-faculty partnerships to study teaching and Learning [blog post]. Retrieved from http://www.centerforengagedlearning.org/student-facultypartnerships-to-study-teaching-and-learning/

Felten, P. (2017). Emotions and partnership. International Journal for Students as Partners, 1(2), 1-5. https://doi.org/10.15173/ijsap.v1i2.3070

Fink, D., \& Stoll, L. (1998). Educational change: Easier said than done. In A. Hargreaves, A. Lieberman, M. Fullan, \& D. Hopkins (Eds.), International handbook of educational change (pp. 297-321). London, UK: Kluwer Academic.

Healey, M., Flint, A., \& Harrington, K. (2014). Engagement through partnership: Students as partners in learning and teaching in higher education. York, UK: Higher Education Academy. Retrieved from https://www.heacademy.ac.uk/knowledgehub/engagement-through-partnership-students-partners-learning-and-teachinghigher

Healey, M., \& Healey, R. L. (2018). 'It depends': Exploring the context-dependent nature of students as partners practices and policies. International Journal for Students as Partners, 2(1). https://doi.org/10.15173/ijsap.v2i1.3472

Higher Education Academy (HEA) (2015). Framework for student engagement through partnership. York, UK: Higher Education Academy. Retrieved from: www.heacademy.ac.uk/sites/default/files/downloads/student-enagagement-throughpartnership-new.pdf

Ingels, J. E. (2009). Ornamental horticulture: Science, operations, \& management. $4^{\text {th }}$ Edition. Clifton Park, NY, USA: Delmar Cengage Learning.

King, C., \& Felten, P. (2012). Threshold concepts in educational development: An introduction. Journal of Faculty Development 26(3), 5-7. Retrieved from https://www.ingentaconnect.com/contentone/nfp/jfd/2012/00000026/00000003/art 00001\#expand/collapse 
Luo, B., Matthews, K. E., \& Chunduri, P. (in press). "Commitment to collaboration": What students have to say about the values underpinning partnership practices. International Journal of Students as Partners.

March, T. (1991). Shaping academic culture: Surviving postmodernism. Liberal Education, 77(2), 2-9. Retrieved from https://eric.ed.gov/?id=EJ430149

Marquis, E., Black, C., \& Healey, M. (2017). Responding to the challenges of student-staff partnership: Reflections of participants at an international summer institute. Teaching in Higher Education, 22(6), 720-735.

https://doi.org/10.1080/13562517.2017.1289510

Matthews, K. E., Dvorakova, S. L., Mercer-Mapstone, L., Acai, A., Cook-Sather, A., Felten, P., Healey, M., Healey, R.L., \& Marquis, E. (2018). Enhancing outcomes and reducing inhibitors to the engagement of students and academics in learning and teaching partnerships: Implications for academic development support. International Journal for Academic Development. https://doi.org/10.1080/1360144X.2018.1545233

Mercer-Mapstone, L., Dvorakova, L. S., Groenendijk, L. J., \& Matthews, K. E. (2017). Idealism, conflict, leadership, and labels: Reflections on co-facilitation as partnership practice. Teaching and Learning Together in Higher Education, 1(21): 1-8. Retrieved from https://repository.brynmawr.edu/tlthe/vol1/iss21/8

Mercer-Mapstone, L., Marquis, E., \& McConnell, C. (2018). The 'partnership identity' in Higher Education: Moving from 'us' and 'them' to 'we' in student-staff partnership. Student Engagement in Higher Education Journal, 2(1), 12-29. https://journals.gre.ac.uk/index.php/raise/article/view/Mercer-Mapstone

Merriam, S.B. (2009). Qualitative research: A guide to design and implementation. 3rd Edition. San Francisco, CA: Jossey-Bass.

National Union of Students (NUS) (2015). A manifesto for partnership: Retrieved from: http://www.nus.org.uk/PageFiles/12238/A\%20Manifesto\%20for\%20Partnership.pdf

Ntem, A., \& Cook-Sather, A. (2018). Resistances and resiliencies in pedagogical partnership: Student partners' perspectives. International Journal for Students as Partners, 2(1): 82-96. https://doi.org/10.15173/iisap.v2i1.3372

Oxford Living Dictionary (2018) Dictionary. Retrieved from: https://en.oxforddictionaries.com

Payne, S. (2007). Grounded theory. In E. Lyons \& A. Coyle (Eds.), Analysing qualitative data in psychology (pp.65-86). London, UK: Sage.

Sheth, J. N., \& Stellner, W. H. (1979). Psychology of innovation resistance: The less developed concept ( $L D C$ ) in diffusion research. Urbana-Champaign, IL: College of Commerce and Business Administration, University of Illinois at Urbana-Champaign.

Smit, B. (2003). The emotional state of teachers during educational policy change. Retrieved from http://www.leeds.ac.uk/educol/documents/00003200.htm

Taylor, C. (2015). A guide to ethics and student engagement through partnership. York, UK: Higher Education Academy. Retrieved from https://www.heacademy.ac.uk/knowledge-hub/guide-ethics-and-studentengagement-through-partnership

Williamson, M. (2013). Guidance on the development and implementation of a student partnership agreement in universities. Edinburgh: Student Participation in Quality Scotland. Retrieved from www.sparqs.ac.uk/institute.php?page $=128$ 
Woolmer, C., Sneddon, P., Curry, G., Hill, B., Fehertavi, S., Longbone, C., \& Wallace, K. (2016). Student staff partnership to create an interdisciplinary science skills course in a research intensive university. International Journal for Academic Development, 21(1), 16-27. https://doi.org/10.1080/1360144X.2015.1113969 